\title{
Study on Carbon Stock of Leasehold Forests of Katakuti VDC, Dolakha District
}

\author{
Tshering Dolma Lama ${ }^{1}$ and Ram Asheshwar Mandal ${ }^{2}$ \\ Corresponding author: Tshering Dolma Lama
}

\begin{abstract}
A study was carried on ten leasehold forests of Katakuti VDC, Dolakha district to estimate the carbon stock. Random sampling was used to collect the biophysical data of trees/ poles, sapling, root and leaf litter, herb and grass. Then, the biomass was calculated using the respective equation and the calculated biomass stock was converted into carbon stock multiplying with 0.47. Similarly, the soil samples were collectewd from different depths of $0-10 \mathrm{~cm}, 10-20 \mathrm{~cm}$ and $20-30 \mathrm{~cm}$ to determine the soil organic carbon. Lastly, all analyzed data were compiled to get total carbon stocks. The result showed that the estimated total carbon stock per ha was found to be highest in Srijana leasehold forest with $125.493 t$ C/ha. The estimated total carbon stock of 10 leasehold forest was found to be 1439.033 tons. Here, Leasehold forests have been an emerging and successful example in conserving forests in epal. So, it is recommended to extend such studies in other parts of Nepal.
\end{abstract}

Key Words: Biomass, Carbon, Carbon Stock, Soil Organic Carbon, Random Sampling

\section{Introduction}

Global warming and climate change are perhaps the most pressing issues these days which are likely to occur as a result of greenhouse gas emissions (IPCC, 2001). At the global scale, deforestation and forest degradation mainly contributes ingreenhouse gasemission. It has been estimated that deforestation contributes to about 17.4 percent of greenhouse gas emission (IPCC, 2007).Here,forest offers a cost effective way to mitigate greenhouse gases and plays a significant role in maintaining the global carbon cycle.Forest store approximately $80 \%$ of terrestrial above-ground, and $40 \%$ of terrestrial below-ground biomass carbon storage (Kirschbaum, 1996) at a global scale. Forest conservation, afforestation, reforestation, and sustainable forest management can provide up to $25 \%$ of the emission reductions needed effectively to combat climate change (Stern, 2006). In Nepal, leasehold forests have been

${ }^{1}$ M.Sc. student, College of Applied Sciences, Kathmandu, Nepal

2 Under Secretary, REDD-forestry and Climate Change Cell/MoFSC/GoN 
playing a major role in conserving forest. Leasehold forests have been contributing in checking deforestation and forest degradation as well as also improve the livelihood of the people. Hence, leasehold forest not only focuses on rehabilitation of degraded forest lands, it is a potential alternative mechanism in poverty reduction.So, the study on carbon stock of leasehold forests is an important research gap in Nepal. Thus, this study was conducted to assess the carbon stocks in leasehold forests.This study helps to establish the baseline information to claim the carbon credit under REDD+ programme in the future.

\section{Materials and Methods}

\section{Study area}

The study was carried on four clusters of ten leasehold forests of Katakuti VDC named Janahit, Muna, Bhimsen, Kalidevi, Kalyankari, Srijana, Siddhiganesh, Setidevi, Sansarimai and Bhumithan leasehold forests.Katakuti VDC lies within Charnawati watershed of Dolakha district of the Central Development Region of Nepal.

\section{Sampling design and Methods of Data Collection}

The map of individual LHF were prepared using the GPS (Global Positioning System) coordinates with the help of Arc GIS software.The number of sample plot in each cluster of leasehold forest was determined by applying proportion allocation method based on the area of leasehold forest.

Altogether 30 sample plots from 10 leasehold forests were carried for the study purpose applying random sampling method maintaining $1 \%$ sampling intensity for each cluster of leasehold forest (CFD, 2004). Then, the coordinates of sample plots were uploaded in the GPS receiver. With the help of the GPS receiver, the plot centre was navigated in the field and the nested plots were established for tree/pole, sapling, seedling, leaf litter, herb, grass and soil. Simultaneously, the slope correction in each sample plot was done whenever required. The $\mathrm{DBH}$ (at $1.3 \mathrm{~m}$ ) and height of individual trees/poles greater than or equal to $5 \mathrm{~cm} \mathrm{DBH}$ were measured but for the saplings $(1-5 \mathrm{~cm})$ only the $\mathrm{DBH}$ at $1.3 \mathrm{~m}$ above ground level were measured. The sample of leaf litter, herb and grasses were collected and carried out in the laboratory to determine the oven dry weight of the biomass. Similarly, the soil samples were collected from three different layers $(0-10 \mathrm{~cm}, 10-20 \mathrm{~cm} \& 20-30 \mathrm{~cm})$ and were brought to laboratory for the analysis of soil organic carbon.

\section{Data analysis}

The allometric equation developed by Chave et al. (2005) and Brown et al. (1989) for moist forest stand was used to estimate above ground tree/pole biomass.The regression model was used to calculate the above ground sapling biomass developed by Tamrakar (2000). Moreover, the samples of leaf litter, herb and grasses were dried to get the biomass. Here, the below ground (root) biomass was estimated as $15 \%$ of above ground biomass (Mac 
Dicken, 1997).Then, the biomass stock was converted to carbon stock after multiplication with the IPCC (2006) default carbon fraction of 0.47. In the context of soil, the carbon stock was calculated as given by Pearson et al. (2007).

Lastly, the total carbon stock was calculated by summing the carbon stock of the individual carbon pools.

Total Carbon stock:

$\mathrm{C}(\mathrm{LU})=\mathrm{C}(\mathrm{ABTG})+\mathrm{C}(\mathrm{AGSB})+\mathrm{C}(\mathrm{BB})+\mathrm{C}(\mathrm{LHG})+\mathrm{SOC}$

Where,

$\mathrm{C}(\mathrm{LU}) \quad=$ carbon stock for a land use category $(\mathrm{t} \mathrm{C} / \mathrm{ha})$

$\mathrm{C}(\mathrm{ABTG})=$ carbon in above ground tree biomass $(\mathrm{t} \mathrm{C/ha})$

$\mathrm{C}(\mathrm{AGSB})=$ carbon in above ground sapling biomass $(\mathrm{t} \mathrm{C} / \mathrm{ha})$

$\mathrm{C}(\mathrm{BB})=$ carbon in below ground (root) biomass $(\mathrm{t} \mathrm{C/ha)}$

$\mathrm{C}(\mathrm{LHG})=$ carbon in litter, herb and grass $(\mathrm{t} \mathrm{C/ha})$

SOC= soil organic carbon $(\mathrm{t} \mathrm{C/ha)}$

\section{Results and Discussion}

\section{Carbon stock of leasehold forests}

The carbon stock of leasehold forests is shown in table 1.

Table 1: Carbon stock of leasehold forests

\begin{tabular}{|l|l|l|l|l|l|l|}
\hline Name of LHF & $\begin{array}{c}\text { C(AGT/PB) } \\
\mathbf{t} \text { C/ha }\end{array}$ & $\begin{array}{c}\text { C(AGSB) } \\
\mathbf{t} \text { C/ha }\end{array}$ & $\begin{array}{c}\text { C(BB) } \\
\mathbf{t} \text { C/ha }\end{array}$ & $\begin{array}{c}\text { C(LHG) } \\
\mathbf{t} \text { C/ha }\end{array}$ & $\begin{array}{c}\text { SOC } \\
\mathbf{t} \text { C/ha }\end{array}$ & $\begin{array}{c}\text { Total } \\
\mathbf{c} \text { corbon } \\
\text { stock } \\
\mathbf{t} \text { C/ha }\end{array}$ \\
\hline Kalyankari & 2.087 & 1.712 & 0.3 & 1.348 & 33.905 & 39.352 \\
\hline Kalidevi & 1.121 & 0.237 & 0.168 & 1.359 & 44.045 & 46.93 \\
\hline Bhimsen & 8.421 & 0.031 & 1.263 & 1.356 & 51.97 & 63.041 \\
\hline Muna & 3.223 & 0.148 & 0.484 & 1.978 & 55.53 & 61.363 \\
\hline Janahit & 1.604 & 0.251 & 0.241 & 1.552 & 94.27 & 97.918 \\
\hline Srijana & 18.702 & 0.652 & 2.805 & 2.464 & 100.87 & 125.493 \\
\hline Siddhiganesh & 9.681 & 0.104 & 1.452 & 1.609 & 52.45 & 65.296 \\
\hline Setidevi & 11.483 & 0.507 & 1.722 & 1.396 & 59.8 & 74.908 \\
\hline Sansarimai & 0.679 & 0.477 & 0.102 & 1.155 & 85.86 & 88.3 \\
\hline Bhumithan & 5.109 & 1.875 & 0.766 & 1.88 & 108.08 & 117.71 \\
\hline
\end{tabular}


Here, the above table shows that the above ground tree/pole carbon stock was found to be highest in Srijana leasehold forest (18.702 t C/ha) because the above ground tree/pole biomass of Srijana leasehold forest was found to be dominant due to occurrence of majority of pole size stand. The above ground sapling carbon stock was found to be highest $(1.875 \mathrm{t}$ $\mathrm{C} / \mathrm{ha}$ ) in Bhumithan leasehold forest because the above ground sapling biomass was found to be more in Bhumithan leasehold forest. The highest leaf litter, herb and grass carbon stock was found to be in Srijana leasehold forest (2.464t C/ha) because the leaf litter, herb and grassbiomass was found to be more in Srijana leasehold forest than other leasehold forests. Removal of forest litters removes most of the nutrients that would otherwise add to fertility of forest bio-mass and increase carbon (Pimentel et al. 1981). The highest SOC was found to be in Bhumithan leasehold forest (108.08 t C/ha) in comparison to other leasehold forests. This might be due to moist and cool climate in Bhumithan leasehold forest than other leasehold forests.The SOC of forest depends on types of climate, moisture, temperature and variation in soil types (Shrestha 2008). Similarly, Smith et al. (2002) reported that SOC increased with elevation due to increase in precipitation, decrease in temperature and production of greater amount of plant biomass at higher elevations.

\section{Total carbon stock}

The total carbon stock of ten leasehold forest was estimated 1439.033tons. The present study shows that the estimated total carbon stock per ha was found to be highest (125.493 t $\mathrm{C} / \mathrm{ha}$ ) in Srijana leasehold forest. The highest estimated total carbon stock per ha of Srijana implies that it bears more good stand trees than other leasehold forests.

\section{Conclusion}

The above ground tree/pole carbon stock, below ground carbon stock and LHG carbon stock was foundto behighest in Srijana leasehold forest. The above ground sapling carbon stock and SOC was foundto be highest in Bhumi than leasehold forest. Theestimated total carbon stock of 10 leasehold forest was found to be 1439.033 tons while the estimated total carbon stock per ha was found to be highest in Srijana leasehold forest.

\section{Recommendation}

- Awareness program on the carbon trade is necessary to promote its importance for leasehold forest users.

- Study on Carbon stock of leasehold forest should be given priority in operational plan of leasehold forest.

- More research and investigation on carbon stock of leasehold forest should be conducted. 


\section{References}

Brown, S., Gillespies, A. and Lugo, A. E. 1989. Biomass Methods for tropical forests with applications to forest inventory data. Forest Science, 35, 881-902.

CFD. 2004. Samudayik Van Shrot Sarbekchyan Margadarshan (Revised, 2004). Community Forestry Division. Department of Forest, Ministry of Forest and Soil Conservation, Government of Nepal.

Chave, J., Andalo, C., and Brown , C. 2005. Tree allometry and improved estimation of carbon stocks and balance in tropical forests. Oecologia, 145: Pages 87-99.

IPCC. 2001. Mitigation, Contribution of Working Group III to the Third Assessment Report of the Intergovernmental Panel on Climate Change, Cambridge (UK): The Press Syndicate of the University of Cambridge.

IPCC. 2007. Climate Change 2007: The Physical Science Basis. Contribution of Working Group I to the Fourth Assessment Report of the Intergovernmental Panel on Climate Change [Solomon, S., D. Qin, M. Manning, Z. Chen, M. Marquis]

Kirshbaum, M.U.F. 1996. The carbon sequestration potential of tree plantations in Australia. In: Environmental Management. The Role of Eucalypts and Other Fast Growing Species.(eds.), Eldridge, K.G., Crowe, M.P., Old, K.M. CSIRO, Forestry and Forest Products, $77-89$.

Mac Dicken, K.G. 1997. A Guide to Monitoring Carbon Storage in Forestry and Agroforestry Project. Forest Carbon Monitoring Program. Winrock International Institute for Agriculture Development.

Pimentel, D., Moran, M.A., Fast, S., Weber, G., Bukantis, R., Balliett, L., Boveng, P., Cleveland, C., Hindman, S. and Young, M. 1981. Biomass Energy from Crop and Forest Residues. Science 212:1110-1115. DOI: 10.1126/science.212.4499.1110.

Shrestha, B. 2008. An analytical Study of Carbon Sequestration in Three Different Forest Types of Mid-Hills of Nepal. M.Sc.Dissertation. Institue of Forestry, Pokhara, Tribhuvan University, Nepal.

Smith, J.L., Halvorson, J.J. and Bolten Jr, H. 2002. Soil properties and microbial activity across a 500m elevation gradient in a semi arid environment. Soil biology and Biochemistry 34:1749-1757.

Stern, N. 2006.The Economics of Climate Change. The Stern Review. Cambridge, UK, Cambridge University Press.

Tamrakar, P.R. 2000. Biomass and Volume Tables with Species Description for Community Forest Management. Ministry of Forest and Soil Conservation, Nepal. 